\title{
MELK wt Allele
}

National Cancer Institute

\section{Source}

National Cancer Institute. MELK wt Allele. NCI Thesaurus. Code C134699.

Human MELK wild-type allele is located in the vicinity of 9p13.2 and is approximately 105

$\mathrm{kb}$ in length. This allele, which encodes maternal embryonic leucine zipper kinase, is involved in protein phosphorylation. Mutation of the gene may be associated with neoplastic diseases. 